\title{
Men's health: a rapidly changing landscape of healthcare delivery and treatment
}

The subspecialty of "Men's Health" is in the midst of an exponential growth spurt. Rapid change and opportunity in the field are promoting progress from the fundamental definition of men's health and the conditions encompassed by the term, to the way that healthcare is delivered to men, down to how treatment of individual male conditions is being redefined. As such, identifying areas where innovation is needed, interpreting key findings, and understanding how healthcare delivery has become more challenging is becoming increasingly important.

This special edition of Translational Andrology and Urology is intended to summarize our current knowledge of key areas of innovation in men's health, as well as how the future of healthcare delivery in men's health is evolving. At the outset, Drs. Jesse Mills and Adithya Balasubramanian discuss how the landscape of men's healthcare delivery and the consumer internet are changing the men's health landscape. Dr. Mills examines how the interface between men's health clinics, pharmacies, telemedicine, and patient access to healthcare is evolving, and Dr. Balasubramanian summarizes how social media and consumer internet platforms like YouTube are impacting how men investigate and learn about conditions affecting them.

Subsequently, we examine innovations in hormone therapy, including how selective androgen receptor modulators (SARMs) and growth hormone secretagogues may influence unique management of hormonal dysfunction and other conditions in men. In particular, these articles focus on the scientific basis for these therapies and their clinical effects. We then segue into further discussion of hormone management with an article by Dr. Ryan Smith on non-testosterone management of hypogonadism, another by Dr. Amin Herati on fertility preservation in men on testosterone therapy. A paper follows addressing sleep and men's health by Dr. Lipshultz, which addresses our growing knowledge of the negative impacts of suboptimal sleep patterns on a number of men's health conditions. These articles highlight important, somewhat controversial areas in men's health in which evolving treatments may have a dramatic impact on men's health in the future. However, the evidence base for a number of these therapies is incomplete, and guidance on whether and how to incorporate these treatments into practice is needed.

As our knowledge of male infertility grows, so does our ability to more effectively evaluate and treat affected men. In the next section of this issue, we examine future diagnostics in male infertility (Dr. Jason Kovac), novel sperm sorting techniques (Dr. James Hotaling), and how male infertility impacts general male wellness (Dr. Michael Eisenberg). Given the growth of transgender medicine and the increases in life expectancy as a result of improvements in cancer treatment, we also highlight fertility preservation options in transgender populations (Dr. Maurice Garcia), as well as sperm preservation more generally in pediatric and adult populations (Dr. Robert Brannigan).

Finally, we focus on erectile function, highlighting future innovation in penile prosthetics (Dr. Tom Lue) and current knowledge regarding regenerative therapies as applied to erectile dysfunction (Dr. Trinity Bivalacqua). We end with a focus on Peyronie's disease, with Drs. J. Scott Gabrielsen and Maarten Albersen discussing the genetic basis of the condition and how the field can move towards improved molecular diagnostics and treatments, respectively. Dr. Laurence Levine then provides an overview of current minimally invasive treatment options for Peyronie's disease, and this section concludes with a discussion of non-conventional therapies for Peyronie's disease by Dr. Ethan Grober.

As editors of this special issue we would like to give our sincere appreciation to all of the contributing authors. This issue of Translational Andrology and Urology represents a dedicated effort by many authors to provide a compendium of highly insightful articles in key areas of men's health. Several of the concepts discussed in this issue, such as SARMs and growth hormone secretagogues may still be considered on the "fringe" of conventional therapy, although the contributing authors demonstrate that there is generally solid science that underlies the effects of these therapies. We hope that our efforts and those of the authors have highlighted areas in the field of men's health that are rapidly evolving and deserve attention and have provided readers with the opportunity to think more broadly about the field of men's health.

\section{Acknowledgments}

Funding: None. 


\section{Footnote}

Provenance and Peer Review: This article was commissioned by the editorial office, Translational Andrology and Urology for the focused issue "Contemporary Issues and Controversies in Men's Health". The article did not undergo external peer review.

Conflicts of Interest: The focused issue "Contemporary Issues and Controversies in Men's Health" was commissioned by the editorial office without any funding or sponsorship. LIL serves as an unpaid editorial board member of Translational Andrology and Urology from Nov 2019 to Oct 2021. LIL and AWP served as the unpaid Guest Editors of the focused issue. Dr. Pastuszak: Endo—speaker, research/fellowship funding, consultant; Woven Health—founder/leadership role; Vault Health— leadership role. Dr. Lipshultz: AbbVie—consultant; Boston Scientific—speaker; Aytu Bioscience—consultant; Endo Pharmaceuticals—speaker/consultant; Lipocine—consultant; Clarus Therapeutics—consultant.

Ethical Statement: The authors are accountable for all aspects of the work in ensuring that questions related to the accuracy or integrity of any part of the work are appropriately investigated and resolved.

Open Access Statement: This is an Open Access article distributed in accordance with the Creative Commons AttributionNonCommercial-NoDerivs 4.0 International License (CC BY-NC-ND 4.0), which permits the non-commercial replication and distribution of the article with the strict proviso that no changes or edits are made and the original work is properly cited (including links to both the formal publication through the relevant DOI and the license). See: https://creativecommons.org/ licenses/by-nc-nd/4.0/.

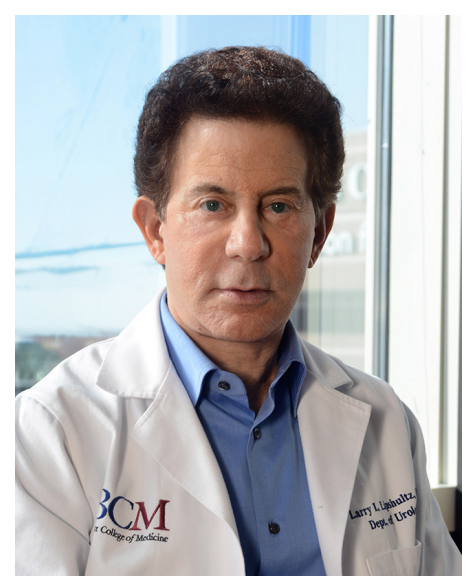

Larry I. Lipshultz

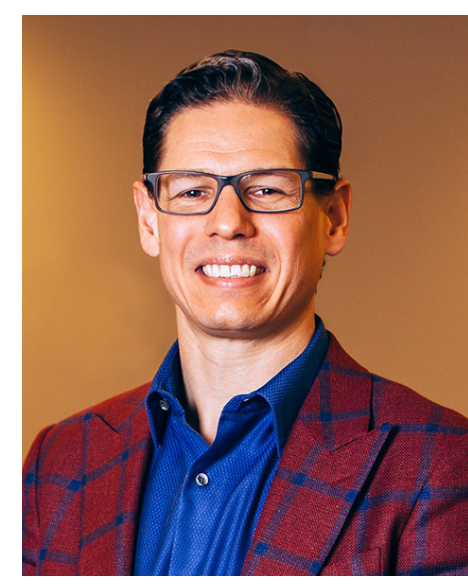

Alexander W. Pastuszak

Larry I. Lipshultz, MD

Scott Department of Urology, Baylor College of Medicine, Houston, TX, USA. (Email: larryl@bcm.edu)

Alexander W. Pastuszak, MD, PhD

Department of Surgery, Division of Urology, University of Utab School of Medicine, Salt Lake City, UT, USA. (Email: Alexander:Pastuszak@utah.edu) Submitted Nov 28, 2019. Accepted for publication Dec 13, 2019. doi: $10.21037 / \operatorname{tau} 2019.12 .30$

View this article at: http://dx.doi.org/10.21037/tau.2019.12.30

Cite this article as: Lipshultz LI, Pastuszak AW. Men's health: a rapidly changing landscape of healthcare delivery and treatment. Transl Androl Urol 2020;9(Suppl 2):S114-S115. doi: $10.21037 /$ tau.2019.12.30 